\title{
THE POTENTIALS AND POSSIBILITIES FOR DEVELOPMENT OF TOURISTIC OFFER IN EASTERN MACEDONIA
}

\author{
MSc. Nikola Bizoev \\ University Goce Delcev 2000 Stip, Republic of Macedonia, \\ Faculty of tourism and business logistic Gevgelija \\ e-mail: bizoev@yahoo.com
}

Professional Paper doi:10.5937/jouproman4-11219

\begin{abstract}
The research of the touristic offer market indicates that the previous touristic arrangements that included a touristic offer of seven or fourteen days is not an attractive offer nowadays. We shall take into consideration the fact that current tourists prefer short vacations. As short trips are more required rather than long trips, the Eastern part of Macedonia has the potential and possibility for success in developing the touristic offer. Trends of short trips shall be the turning basic point when creating the touristic offer in this part of Macedonia. The private accommodation in the Eastern part of Macedonia is closely related to the rural way of living, which is a great advantage comparing to enormous hotels, as tourists expect to experience a difference. For this purpose, tourists must be offered with activities with which certain destinations would be sold as a unique touristic product with precised and interesting story, authentic offer and high quality accommodation infrastructure. This kind of sell requires numerous activities and contracts between local communities, agencies and local entrepreneurship. It is necessary the destination management to be on a high functional level as previous experiences include excellent results.
\end{abstract}

Key words: short vacations, destination management, family accommodation, authentic offer

\section{Introduction}

The regions from Eastern Macedonia have certain unique elements as cultural monuments, possibilities for active vacation in a village and towns, qualitative gastronomic offer and other interesting animations that can offer a lot of amusing stories. People have started to undertake numerous activities that will assist in attracting more tourists in this region. However, the problem has appeared because of the lack of qualitative programs that shall actually guide those activities in the field of organization, merging and promotion.
On regional level, tourist workers and local authorities transfer the organization obligation between themselves and the same stories are spinned about who should play the key role instead of actually achieving an appropriate agreement between both sides. It is still present the opinion from the past that tourist accommodation in large hotels would increase the promotion of Macedonian tourist brand. Moreover, it is still thought that from the first group of tourists a lot of money would be earned.

Partially it is as result of the lack of family tradition in tourism and the entrepreneurship spirit of people whose occupation is providing tourism services as well as the low qualification of tourism education. Tourist agencies in Eastern Macedonia usually offer summer arrangements for lake or sea and are the cases when a certain tourist agency attempts to create their own incoming program are really rare. According to their opinion the main reason for this mode of work is the lack of sufficient capacities in the mentioned destinations i.e. the problem with finding accommodation for bus groups.

We definitely assume that this type of opinion would be changed in the moment when in their programs would be included and promoted accommodation capacities such as small and family hotels and apartments that can be easily integrated in the offer ambient and should be built in this region. 
The examples from the practice of the developed touristic countries in the world have indicated that the future development of tourism is based on these touristic capacities. The statement that accommodation is the weakest point in the touristic offer of continental tourism should not be repeated again. Accommodationsas private shelters for night, guest houses, rooming house and similar tourist capacities without previous criteria for their categorization is not acceptable option anymore.

\section{Situation with the tourism development in the region of Eastern Macedonia}

The South East region is located at the southeast part of the Republic of Macedonia and comprises the region of Strumica, Radovish, Valandovo and Gevgelija valley, actually the valley of the river Strumica and the low flow of the river Vardar. According to the data from 2003, the region has a population of $8.4 \%$ from the total population of the Republic of Macedonia. It covers $10.9 \%$ of the total area of the country, with a population density of 63.3 people per $\mathrm{km}^{2}$. The region has a rich hydrographic network a large number of sunny days, the favorable climate and pedological conditions that characterize the region as largely agricultural. The region is known for its quality and volume production of early vegetables, fresh vegetables and fruits. According to the production of grapes this region is second in Macedonia after the Vardar region having $25 \%$ of total production in $2013^{1}$. Although the possibilities of this region are very large in recent years it is not noticed any particular increase in tourism, particularly in number of tourist visits and the number of overnight stays by foreign tourists. In the period $2011-2013$ the total number of tourists decreased by $1.08 \%$, while the total number of overnight stays increased by $1.33 \%$ with overnight stays of foreign tourists decreased by $1.69 \%$, while overnight stays of domestic tourists increased to $2.81 \%$. Nearly the same percentage is decreased in the number of foreign tourists who visited the region. So the number of domestic tourists is increasing while the number of foreign tourists is decreasing. The eastern region is mostly mountainous region and covers the far east of the country. It extends along the river Bregalnica or running through Stip, Maleshevsko - Pijanechka Valley and Kocani Field. The region covers $14.2 \%$ of the total territory of Macedonia with $8.6 \%$ of the total population (2013) and a population density of 50.4 people per $\mathrm{km}^{2}$. Mountainous terrain in this region is strong potential for development of winter tourism and alternative tourism. The active role of the municipality of the Eastern region in recent years in the field of touristic promotion and development has had a huge contribution in the implementation of the campaign "Come to the east". The region has a very rich cultural heritage and numerous natural beauties that are not sufficiently promoted and exploited. Special and perhaps the most important accent is given to the archeological/cultural tourism, because the Slavic alphabet and literacy was created in this region in the ninth century around Bregalnica. The region already boasts with examples of tourist offer of the intangible cultural heritage protected by UNESCO. In the period 2011-2013 the total number of tourists in the region has increased by 0.85 $\%$ while the total number of overnight stays increased by $0,63 \%$, and overnight stays of foreign tourists increased slightly while overnight stays of domestic tourists increased by $0,85 \%$.

\footnotetext{
${ }^{1}$ State statistical office of the republic of Macedonia(2014). Regions of the Republic of Macedonia, Skopje. Regional yearbook (112). 
The Eastern region is one of the least visited regions by tourists and therefore more attention should be paid to the development of tourism taking into account the possibilities for valorization of the resources that exist here. The northeast region covers the northeastern end of the country and extends along the river Pcinja and the river Kriva Reka. The region is one of the smallest regions and covers $9.3 \%$ of the total area of the Republic of Macedonia, with a population that is $8.5 \%$ of the total number of population density of 76.1 people per $\mathrm{km}^{2}$. Natural conditions and resources of the northeast region offer potential for development and improvement of breeding and development of meat and dairy food industry. What is typical for the region is that in 2012 it participated with only $5.8 \%$ of total GDP, which is the smallest participation compared to other regions. In 2013 the employment rate was the lowest compared to other regions and it was $29.9 \%$, while the unemployment rate was the highest at national level and it was $44.9 \%$. In 2013 were recorded at this region at least domestic tourists $(0.61 \%)$ and least foreign tourists $(0.93 \%)$. Although the region has unique examples of cultural historical heritage and natural rarities and beauties worthy for tourist valorization, unfortunately, they are not promoted enough in order to be a motive for a tourist visit.

\section{Analysis of the possibilities of tourist offer in the regions of eastern Macedonia}

As the offer like bed and breakfast (B $\&$ B) does not change the static situation of the development of Macedonia's tourism brand, it is strongly believed that tourism development should be directed towards a different offer in other parts of the country. In this direction, we are focused on the necessity for adopting measures to encourage the development of rural tourism on regional level. The opportunities for development of tourism offer in rural areas of eastern Macedonia will be shown through SWOT analysis:

\section{Strenghts:}

- The interest of the local population to provide services in family accommodation is growing.

- The number of service providers who possess "active tourism and catering literacy" is increasing.

- Foundations for local development are of greater importance in the commercialization of family restaurants.

- Most of the catering facilities are built near the attractive micro locations .

- The quality of the tender orientation etc. "Green tourism" is increasing .

- The number of tourists seeking accommodation services in rural areas is rising

- Awareness among service providers about the importance of individual approach towards guests and the meaning of the term"Good value for money" is developed

\section{Weaknesses}

- There is no equal quality on offer.

- Large number of " incompatible" apartment buildings that have no system for quality management.

- Lack of professional competence among providers of tourist services

- Still no vision for the development of tourism offer the type of small family hotels.

- A small number of service providers where tourism is the main source of income.

- Dominance of seasonal working with offers which will include themes.

○ Very weak marketing promotion and lack of recognizable regional brand.

- Lack of horizontal and vertical cooperation in the tourist offer. 


\section{Opportunities:}

- Applying international examples of good practice when providing travel services

- Participation in international projects and using EU funds for development

- Promotion of intangible cultural heritage of the region which is on the list of UNESCO

- Utilization of services by electronic cadastre in spatial planning of new buildings

- Development of niche forms of tourism offer as cycling tourism, sustainable tourism and so on.

- Using on demand etc. "Green" and "lifestile" accommodation which is larger

- Understanding the needs of the public - private collaboration

\section{Threats:}

- There are still providers of tourist services possessing "catering elementary literacy"

- It is difficult to establish a complete value chain destination

- Illegal buildings still exist

- Localities have image of cheap tourist destination

- Environmental degradation of the area is present next to some tourist sites

- The business environment in the region is opaque

- Insufficient interest of the state for development of rural tourism in the region

- Insufficient care to eliminate corruption at local level

As a very important factor in raising the level of quality of touristic offer in the region of eastern Macedonia are considered to be human resources. It is necessary to raise the awareness for the importance and the key role of people when providing services and creating satisfaction among the guests. The image of the destination is created by the competence and quality of the staff and not just by those directly employed in tourism but also by those indirectly involved in tourism trends and the same ones that make profit from them. ${ }^{2}$ According to the results from the research at catering literacy level conducted to a larger number of micro entrepreneurs in rural areas of Eastern Macedonia, we have concluded that most of them have active catering literacy. This literacy means ability of the caterer after the completed high school catering and tourism school to apply the knowledge in practice to other entrepreneurs or self- drive business. The number of entrepreneurs that have creative hotel and tourism literacy is fewer. People with this kind of literacy have high or higher education, extensive work experience in their sphere of working, experience in creating different forms of tourist offer and sales, know and want to apply all rules, laws, standards and familiar solutions in the field of catering. ${ }^{3}$ The fewest number of entrepreneurs are those with elementary catering literacy that are occupied with tourism due to the possibility and catering in order to gain income in quick manner or having extra "free" financial assets from other services. These persons have negative effect rather than positive effect on tourism development.

\section{Potentials for tourism development in the regions from East Macedonia}

Although Macedonia has growth rates in the number of arrivals and in the number of nights, tourism is still stagnating in revenues and in investments. Stagnating is especially evident in that part of the country where tourism can be instigator of economic development and in areas such as small rural areas.

\footnotetext{
${ }^{2}$ Dronjič, B. (2003). Man-The key to success in tourism. UTProfessional magazine for tourism, Zagreb, num. 4

${ }^{3}$ Galičič, V. (2005)..Catering literacy. UT

Professional magazine for tourism, Zagreb. nom.4 (82).
} 
Data from the Statistical Office of the Republic of Macedonia confirm the necessity for increased activity for offer development in rural areas where the leading offer would be the rural type of tourism offer. With exception of the region of Skopje and part of the Southwest region, all other regions in Macedonia, mainly rural areas with excellent possibilities for tourism development have fewer tourists ${ }^{4}$.

According to the number of rooms and number of beds, all three regions of Eastern Macedonia in 2013 participated all together with only $12 \%$, while the number of tourists and the number of nights spent their share stands at $19 \%$ and $17.5 \%$. In order to assets that this situation does not correspond to the potentials for tourism development of this region, we have conducted a research where the target group in the region were micro entrepreneurs. The survey covered owners of 53 buildings (mainly private homes for renting and villas), where are employed 117 people from 16 municipalities and towns in eastern Macedonia. With the purpose of confirming the thesis that regions from the East part of Macedonia have potential of rural tourism development we explain the results.

On the question on the form of the registration of the company, the inquired entrepreneurs have given the following responses.

\footnotetext{
${ }^{4}$ National strategy for rural tourism, 2012-2017 (14). Ministry of Economy, Department of Tourism. Skopje,

${ }^{5}$ State Statistical Office of the Republic of Macedonia (2014). Regions of the Republic of Macedonia, Skopje. Regional yearbook (114).
}

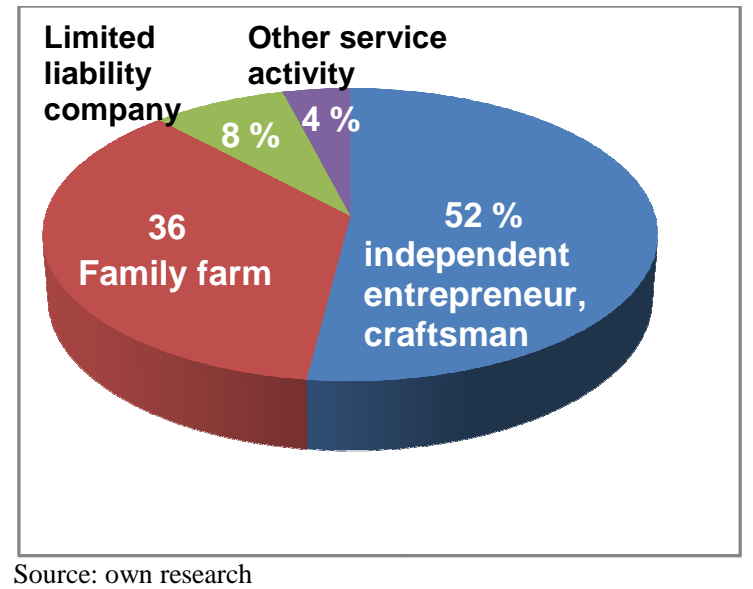

Figure 1. Form of registration of companies

The responses on the question about the number of family members involved in family business are given in table 1:

Table 1.Number of family members involved in family business:

\begin{tabular}{|l|c|}
\hline none & 4 \\
\hline from 1 to 2 & 29 \\
\hline from 3 to 4 & 12 \\
\hline 5 and more & 8 \\
\hline
\end{tabular}

Source: own research

Responses to the question about the most important products and services from which the entrepreneurs gain the high profit are given in the table 2 :

Table 2. Products and services from which the highest profit is gained

\begin{tabular}{|l|c|}
\hline products and services & participation \% \\
\hline Accommodation & $75 \%$ \\
\hline Food & $12 \%$ \\
\hline $\begin{array}{l}\text { Accommodation and } \\
\text { food }\end{array}$ & $8 \%$ \\
\hline Trade & $5 \%$ \\
\hline
\end{tabular}

Table 3.Annual revenues

\begin{tabular}{||l||c||}
\hline \multicolumn{1}{|c|}{ in euro } & in percent \\
\hline up to 5.000 euro & $38 \%$ \\
\hline from 5.000 to 10.000 euro & $54 \%$ \\
\hline more than 10.000 euro & $8 \%$ \\
\hline Source: own research
\end{tabular}

The shown results in table 3 has given the answer to the question about the extent of the annual incomes of entrepreneurs from family business in 2015 . 
The responses to the question for the evaluation of the entrepreneurs' performance in 2015 graphically can be presented in circle structure:

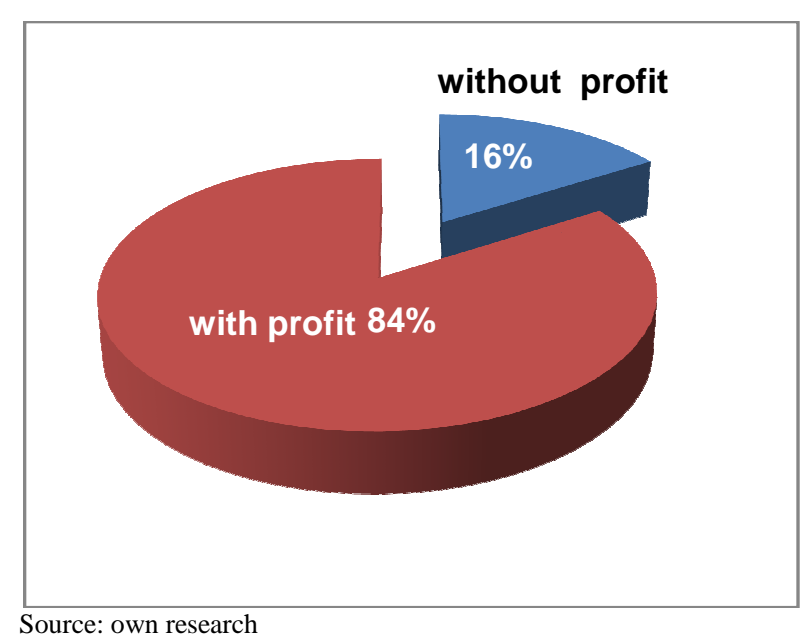

Figure 2.Evaluation of performance in 2015

On the question whether the entrepreneurs have planned new investments in 2016 and to what extent, the entrepreneurs responded as follows:

Table 4.Planning of new investments

\begin{tabular}{||l||c||}
\hline \hline amount of investment & in percent \\
\hline I do not plan & $35 \%$ \\
\hline up to 5000 euro & $22 \%$ \\
\hline 5.000 to 10.000 euro & $18 \%$ \\
\hline more than 15.000 euro & $25 \%$ \\
\hline
\end{tabular}

\section{Conclusion}

The lack of regional or local sectors that shall be authorized for promotion of touristic destination brands in eastern Macedonia is one of the main reasons for the weak touristic development. Also, the Law on touristic services (Article 51) is not in compliance with the concept for creation of small business in rural areas because the services for rural, ethno and ecotourism may be provided by a physical person. There is no precise definition for the term rural tourism according to the standards of the World Tourism Organization. This insufficiency is the cause of many inconsistencies when providing tourist services in rural areas. How to explain the fact that the region of northeastern Macedonia, which abounds with authentic offers such as Byzantine art and architecture from the XI and XIV century, small medieval towns megalithic observatory, ethno village, mountains rich in springs, mountain resorts, forest plants and fruit has minimum touristic visits by domestic and foreign tourists? However, in order all this to function properly it is needed a qualitative destination management for which there is no solution. At numerous destinations this mode of work it is not even mentioned. According to the current situation the touristic offer in the regions is from the type "mono product" i.e. all tourist providers offer the similar or the same products and services. It should be taken into account that each region is specific in a certain feature according to which the offer will be created, for example, hunting offer, offer of fishing, religious, cultural, health, active, caving, mountain tourism, biking and more. No matter which form of tourism we are concerned, in these programs should always be promoted accommodation facilities, such as small family hotels and boarding houses that fit the ambience of supply and that need increasingly to be built in these regions.

\section{References}

1. Bartoluci, M. (2013). Upravljanje razvojem turizma $i$ poduzetnistva. Turisticka politika, razvoj i poduzetnistvo u turizmu. Skolska Knjiga, Zagreb.

2. Dronjič, B. (2003). Man-The key to success in tourism. UTProfessional magazine for tourism,Zagreb, num. 4

3. Galičič, V. (2005)..Catering literacy. UT Professional magazine for tourism,Zagreb. nom.4 (82).

4. Kukina, M. P. (2009). Destinacijski menadzment. Zajednicki cilj mamac za turiste. Strucna revija za turizam $U T,(09-10)$. 
5. Kunst, I. (2011). Upravljanje turistickom destinacijom, Izazovi upravljanja turizmom, Institut za turizam, Zagreb

6. Magas, D. (2010, Maj). Destinacijski menadzmenti sustav turistickih zajednica. UT Strucnarevijazaturizam, Zagreb.
7. National strategy for rural tourism, 2012-2017 (14). Ministry of Economy, Department of Tourism. Skopje

8. State Statistical Office of the Republic of Macedonia (2014). Regions of the Republic of Macedonia, Skopje. Regional yearbook (114). 